\title{
THE RELATIONSHIP BETWEEN THE COST LEADERSHIP STRATEGY AND THE QUALITY OF HEALTH SERVICES IN KENDARI CITY HOSPITAL
}

\author{
Fitri Ayu Santri ${ }^{1}$, La Ode Saafi ${ }^{2}$, La Ode Kamalia ${ }^{3}$ \\ ${ }^{1,2,3}$ Master of Public Health Study Program, Universitas Mandala Waluya, \\ Kendari, Southeast Sulawesi, Indonesia
}

Corresponding Author : Fitri Ayu Santri

\section{Abstract}

Background: A hospital in Kendari is tracing the problems namely about interactions with employees. Also the information about the strategies which is used to improve hospital performance has not been clearly stated. The efforts to improve services are still relatively routine in nature. The use of strategic terms is still relatively traditional, so the strategic position of this hospital is unclear. The purpose of this study is to analyse the relationship between the cost leadership strategy and the quality of health services in Kendari City Hospital.

Methods: This research is quantitative study with a cross sectional approach. The research location was in the Kendari City Regional Hospital and was conducted from February to March 2021. The population was 456 people and a sample of 95 people was all employees of the Kendari City Regional Hospital. The sampling technique used the Proportive Random Sampling.

Results: There is a relationship between Cost leadership strategy with Service Quality, it is known that the value of chi square $\left(\mathrm{X}^{2}\right.$ count is greater than $\mathrm{X}^{2}$ table, and a value of Phi is 0.239 or it lies between $0.20-0.399$. This means that there is a weak relationship.

Conclusion: Offensive Strategy or Growth is a strategy that is recommended to improve the quality of services in the Kendari City Regional Hospital.

Key words: Cost, Leadership, Strategy, Service, Quality, Patient 


\section{INTRODUCTION}

The quality of health services today is a major issue. The health services quality is the social demands for all social strata, in the upper class society and in the lower class society. This can be seen from the fact that the use of health care facilities by the upper class to neighboring Malaysia and Singapore has increased and the lower class demands service to the VIP class in their own country in Indonesia because the service is comparable / only that of quality and possible.(1). Therefore, it takes a lot of energy in efforts to change people's behavior in line with the health development $\operatorname{program}(2)$.

In line with the limited state budget for the health sector, the government policy is to refer to the financing system, namely being under health service facilities as a Public Service Agency where the central hospital is the reference and RSD becomes the Regional Public Service Agency. This is in accordance with the law. RI No. 44 of 2009 concerning the concept of a hospital becoming a Regional Public Service Agency, in essence, the hospital's expenditure budget is fully obtained from the patient's pocket (out-ofpocket) for the trip, while the Regional Public Service Agency partially or at least $40 \%$ of the patient's pocket and $60 \%$ of the government whose target is to civil servant salaries and investment (3).

Based on the concept of the agreement and the Regional Public Service Agency above, the hospital needs the ability to use the right strategy to achieve the goals set both primary and secondary goals. The primary goals of the hospital include BOR, LOS, BTO, TOI, GOR, and NDR (C. barbar jhonson), Economic indicators include service quality and patient safety, patient and family satisfaction and employee satisfaction, while the secondary objectives are the development of hospitals from low to high classes and employee welfare.

Service quality is something that consumers get from service providers (companies or organizations) with reference to consumer satisfaction indicators. Quality of service must allow the company / organization to provide the maximum amount of service to consumers to satisfy loyal customers. Service quality has a positive effect on customer satisfaction, especially in health services(4).

The hospital as one of the middle health services is one of the health facilities provided by the local government to serve the needs of the community(5). Hospital is a container in the national health system and has a mission to provide health services to the entire community, because the development and management of health in hospitals need to be directed at national goals in the health sector, and it is not surprising that the health sector requires sustainable treatment to serve the community in health aspects. Speed, accuracy, cheap and friendly which is intended and of course expected by the community. Given that the country can develop well with the support of a healthy body and soul. In order to retain customers, the hospital must always pay attention to the needs of consumers to maintain consumer confidence and to meet the needs and expectations of the services provided.(6).

Kendari City Regional General Hospital is a Class $\mathrm{C}$ public hospital based on the Law of the Southeast Sulawesi Provincial Health Service Number 188/1807 / Yankes Dinkes Operational Director of Class C Hospital. Kendari City Hospital has 133 rooms and 271 medical personnel who work (7).

From a geographical point of view, Kendari City Hospital is in a very strategic position because it is located in the vicinity of a luxury housing complex, adjacent to hotels and offices and on the main route. However, other factors are still lurking, such as problems in the area of building expansion that will experience obstacles. From the managerial side, Kendari City Hospital is still far behind its competitor hospital, the Southeast Sulawesi Provincial Hospital. Therefore, Kendari City Hospital needs the right strategy to improve the hospital's 
Santri, F. A., Saafi, L. O., \& Kamalia, L. O. DOI: 10.36566/ijhsrd/Vol3.Iss2/81

performance that is better than other hospitals.

\section{METHOD}

The type of research is quantitative research which is based on a cross section design approach.The research location at the Kendari City Regional Hospital was conducted from February to March 2021. The population was 456 people and a sample of 95 people was all employees of the Kendari City Regional Hospital. The sampling techniqe used Proportive Random Sampling. The sample in this study is a sample which can provide information in this case of the staff of Kendari City Hospital.

\section{RESULT}

Table 1 is known that from a total of 99 respondents who stated that the quality of service was good, there were 71 people (71.71\%), but there were several respondents who stated that the quality of service was still lacking because there were still

Table 1

Distribution of Service Quality Frequency in Kendari City Hospital

\begin{tabular}{ccc}
\hline Quality of Service & Frequency (f) & Percentage (\%) \\
\hline Good & 71 & 71.71 \\
Less & 28 & 28.29 \\
\hline Total $(\mathrm{n})$ & 99 & 100 \\
\hline
\end{tabular}

Table 2

Frequency Distribution Cost leadership strategy

\begin{tabular}{ccc}
\hline Cost leadership strategy & Frequency (f) & Percentage (\%) \\
\hline Good & 78 & 78.78 \\
Less & 21 & 21.22 \\
\hline Total $(\mathrm{n})$ & 99 & 100 \\
\hline
\end{tabular}

Table 3

Relationship Cost leadership strategy with Service Quality Improvement in Kendari City Hospital

\begin{tabular}{|c|c|c|c|c|c|c|c|c|}
\hline \multirow{3}{*}{$\begin{array}{c}\text { Cost } \\
\text { leadership } \\
\text { strategy }\end{array}$} & \multicolumn{4}{|c|}{ Quality of Service } & \multirow[t]{3}{*}{$\Sigma$} & \multirow[t]{3}{*}{$\%$} & \multirow{3}{*}{$\begin{array}{c}\text { Chi- } \\
\text { Square }\end{array}$} & \multirow[t]{3}{*}{$\mathrm{X}$ table } \\
\hline & \multicolumn{2}{|c|}{ Less } & \multicolumn{2}{|c|}{ Good } & & & & \\
\hline & f & $\%$ & f & $\%$ & & & & \\
\hline Less & 11 & 39.3 & 17 & 60.7 & 28 & 100 & $4,456 \quad 0.239$ & 8 \\
\hline
\end{tabular}

Indonesian Journal Of Health Sciences Research and Development 
Santri, F. A., Saafi, L. O., \& Kamalia, L. O.

DOI: 10.36566/ijhsrd/Vol3.Iss2/81

https://ijhsrd.com/index.php/ijhsrd

e- ISSN: 2715-4718

\begin{tabular}{lllllll} 
Good & 12 & 16.9 & 59 & 83.1 & 71 & 100 \\
\hline Total $(\mathrm{n})$ & 23 & 23.2 & 76 & 76.8 & 99 & 100
\end{tabular}

DISCUSSION

\section{Overview of Quality Improvement Strategies in Kendari City Hospital.}

DaThe results of the SWOT matrix diagram found a strategy that can be used as the main strategy in improving the quality of services in Kendari City Hospital, namely Kendari City Hospital, which can use the Offensive or Growth Strategy.

New Market Entryis an offensive strategy in entering a new attractive market. Where the Kendari City Hospital is a form of hospital that is relatively new but the acceleration of development is relatively fast. New market development strategies require a large investment in resources in each firm and may operate at a certain level of loss until market volume reaches breakeven levels. Although this market is attractive and growing, this form of service will come under increased attack conditions due to new competitors having almost the same services and close positions (8).

These offensive strategies can range from improving competitive position and market share in current market products to entering a new market with an unspecified market position, an example where the health services at the Kendari City Regional Hospital are almost the same as those owned by an adjacent private hospital. , the market is meant to be Kendari City Hospital or the company in general. RS explores the possibility of using an offensive strategic market plan to seek to emerge in an undeveloped service where RS will have a strong position of advantage and is part of its trademark (9).

Offensive strategic market plans are basically carried out to grow and involve strategies that are penetrating or grow the current market or enter and develop new markets. Several alternatives to this offensive strategy are: (1) investing to grow current promotions, with the aim of growing the current market: growing market share, growing revenue per customer, entering new market segments, and expanding market demand; (2) investing to improve competitive position, with the aim of improving margins: improving customer loyalty and retention, improving differentiation advantage, lowering costs or improving marketing productivity, and building marketing advantage; (3) investment to enter global markets, with the aim of diversifying growth: entering new related markets, entering new unrelated markets, entering new growing markets, and developing new markets. The choice of one strategic offensive market plan over the other depends on the hospital's profit requirements, resources and strategic position, and the need to analyze opportunities for growth (10).

It can be concluded that there is a need for the development of the Kendari City Regional Hospital to improve the various types of services that are different from the services of the Competing Hospital. Seeing the strategic position close to elite housing and star hotels and added administrative services to the city health office is relatively fast and efficient so that supervision and improvement of service quality is an integral part of seeing the quality or quality of Kendari City Hospital.

\section{The relationship between the cost leadership strategy factor towards improving the quality of service at the Kendari City Regional Hospital.}

The results of this study found that there was a relationship between Cost leadership strategywith Service Quality, it is known that the value of chi square / X count is greater than $\mathrm{X}$ table. With a value of Phi 0.239 , it lies between 0.20-0.399, which means that there is a weak relationship.

After determining the mission, vision, value guidelines and development issues, the hospital will determine a strategy to carry out the mission and achieve the vision it 
aspires to. Logically, strategy formulation stems from institutional diagnoses that raise questions about what to do in the future. In the context of this uncertainty, strategy can be said as a hypothesis about which therapy is taken and will be applied. Thus, before it is implemented, strategy formulation is a hypothesis that is not necessarily proven to be useful for achieving something. In the process, there are various activities such as testing strategies, Implementation of the Balanced Scorecard Budget Strategy Trials (11).

Competitive advantage is the ability of a company to obtain economic benefits above the profits that competitors can achieve in the market in the same industry. Companies that have a competitive advantage always have the ability to understand changes in market structure and are able to choose effective marketing strategies. The strategy is a generic strategy that is classified into three categories, namely cost leadership, differentiation, and focus. Each company's choice of the generic strategy above will depend on an analysis of the business environment to determine opportunities and threats.

In order to achieve a competitive advantage, a company must have an "appropriate" competitive strategy. Two factors are taken into account in achieving the "right" competitive strategy. First, based on the competitive advantage of the organization. This competitive advantage can only be obtained from one of two sources: either from the advantages of creating low costs (cost leadership), or from the ability of the organization to be different (differentiation) from its competitors. The second factor in this approach is productmarket coverage (competitive scope) in which organizations compete with each other in a broad and narrow market. The combination of these two factors forms the basic strategy of Porter's generic competitive strategy, namely: 1) cost leadership is a strategy used by an organization if the organization wants to become a low cost market leader with a broad customer base; 2) differentiation (defferentiation) is a strategy used by the organization if the organization wants to compete with its competitors in terms of the uniqueness of the products and services offered. It can be in the form of: prestige and brand image, technology, innovation, features, customer service, dealer network; and 3) Focus (cost or differentiation based) organizations with a focused strategy serving the specific needs of a market niche. Organizations can choose a cost-based or differentiation-based focus 2) differentiation (defferentiation) is a strategy used by the organization if the organization wants to compete with its competitors in terms of the uniqueness of the products and services offered. It can be in the form of: prestige and brand image, technology, innovation, features, customer service, dealer network; and 3) Focus (cost or differentiation based) organizations with a focused strategy serving the specific needs of a market niche. Organizations can choose a cost-based or differentiation-based focus 2) differentiation (defferentiation) is a strategy used by the organization if the organization wants to compete with its competitors in terms of the uniqueness of the products and services offered. It can be in the form of: prestige and brand image, technology, innovation, features, customer service, dealer network; and 3) Focus (cost or differentiation based) organizations with a focused strategy serving the specific needs of a market niche. Organizations can choose a cost-based or differentiation-based focus(12).

The low cost strategy (the cost of leadership) is a series of integrative actions to produce and offer goods or services at the lowest cost to competitors with characteristics that are acceptable to customers. If the company offers a product or service with standard quality, but the cost is much lower than industry costs, then the organization will be said to be superior in cost and / or price. 
Hospitals that have a comprehensive cost advantage can take advantage of this advantage to charge lower prices or take higher profit margins. Hospitals that are able to make products at lower costs in this case rates with better service than competitors, thus attracting more visits, thus the Hospital is in a better position, where it can enable the company to survive in a competitive price war situation and deter competitors with higher costs, Higher profits can be invested to improve quality and efficiency, The possibility of producing economies of scale, but many firms do not take advantage of it (due to limited capital, information and others) or An increase in raw materials from suppliers can be dampened by a cost advantage. With a low cost strategy, it is an economy of scale, which is the goal of achieving a minimum measure of efficiency between the input-output relationship, and high quality products (13).

In this study, the researchers assume that the Cost Lidership Strategy is a part that cannot be separated in improving the quality or quality of service because efforts to gain a competitive advantage by increasing sales through the lowest price competition is the hope for the community as hospital service users, and with a state hospital is a state hospital. opportunities that are not difficult to implement this strategy. The lowest cost strategy is to minimize the costs of getting the product or service at the lowest price.

\section{CONCLUSION}

There is a weak association between the which is recommended to improve the quality of services at the Kendari City Regional Hospital. Therefore, implementation of the periodic evaluation of service quality is needed to find out market needs.

\section{REFERENCES}

1. Neng Kamarmi S. Analisis pelayanan publik terhadap masyarakat (Kasus pelayanan Kesehatan di Kabupaten
Agam). Jurnal Manajemen dan Kewirausahaan. 2011;2:84-110.

2. Jayadipraja EA, Prasetya F, Azlimin A, Mando WOSY. Family clean and healthy living behavior and its determinant factors in the village of Labunia, Regency of Muna, Southeast Sulawesi Province of Indonesia. Public Health of Indonesia. 2018;4(1):39-45.

3. Widada T, Pramusinto A, Lazuardi L. Peran badan penyelenggara jaminan sosial (bpjs) kesehatan dan implikasinya terhadap ketahanan masyarakat (studi di rsud hasanuddin damrah manna kabupaten bengkulu selatan, provinsi bengkulu). Jurnal Ketahanan Nasional. 2017;23(2):199216.

4. Agritubella SM. Kenyamanan Dan Kepuasan Pasien Dalam Proses Interaksi Pelayanan Keperawatan Di Rsud Petala Bumi. Jurnal Endurance. 2018;3(1):42-54.

5. Akbar MI. Survey Tingkat Kepuasan Pasien Rawat Jalan Terhadap Pelayanan RSUD Kabupaten Buton Utara. Jurnal Kesehatan Masyarakat Celebes. 2020;1(04):1-8.

6. Listiyono RA. Studi Deskriptif Tentang Kuaitas Pelayanan di Rumah Sakit Umum Dr. Wahidin Sudiro Husodo Kota Mojokerto Pasca Menjadi Rumah Sakit Tipe B. Jurnal Kebijakan Dan Manajemen Publik. 2015;1(1):2-7.

7. Murtina H, Mailasari M. Pengukuran Tingkat Reliabilitas Metode Simple Additive Weighting Menggunakan Metode Pearson Correlation. INFORMATION SYSTEM FOR EDUCATORS AND PROFESSIONALS: Journal of Information System. 2017;2(1):21-3021-30.

8. Sudibyo AR. Hubungan Antara Kualitas Pelayanan Dengan Kepuasan Pasien Terhadap Pelayanan Di RSIA Srikandi IBI Jember Tahun 2014. 2014. 
Santri, F. A., Saafi, L. O., \& Kamalia, L. O.

DOI: 10.36566/ijhsrd/Vol3.Iss2/81

https://ijhsrd.com/index.php/ijhsrd

9. Bakara A, Suratman D. Perkembangan Kognitif Siswa Dalam Operasi Logis Berdasarkan Teori Piaget Di Sekolah Menengah Pertama. Jurnal Pendidikan dan Pembelajaran Khatulistiwa. 2015;4(12).

10. Nauval AF. Formulasi Strategi Untuk Pengembangan Pasar Industri Semen Di Jawa Timur (Studi Kasus Perusahaan "A"): Institut Teknologi Sepuluh Nopember; 2017.

11. Malichah A. Pengaruh Layanan Konseling Kelompok Dengan Teknik Behavior Contract Terhadap Pengurangan Perilaku Membolos Siswa Kelas XII SMK Negeri 4 Semarang Tahun Ajaran 2016/2017: Universitas Negeri Semarang; 2016.

12. Widajanti E. Pengaruh Retailing Mix Terhadap Keputusan Pembelian Konsumen (Studi Kasus Pada Konsumen Luwes Group Surakarta). Jurnal. 2014;27(1).

13. Merliana V, Kurniawan A. Pengaruh Strategi Biaya Rendah dan Diferensiasi terhadap Keberhasilan PT Tahu Tauhid. Jurnal Manajemen Maranatha. 2016;15(2). 